\title{
Wingkorolls Instagram Marketing Strategy
}

\author{
I Muslimah \\ Faculty of Social and Political Science, Universitas Diponegoro, Semarang, Indonesia \\ \{risa_spensaa@yahoo.com $\}$
}

\begin{abstract}
Nowadays, the social media change the marketing strategy into online business such as through facebook, twitter, Instagram, etc. Instagram in presentday becomes social media that online business or common people used massively. According to APJII 2016, an Instagram user in Indonesia was $15 \%$ more than the user of Youtube and Twitter. $62 \%$ of which, used it for online shopping and 34.2\% utilized for personal business. Now, many actors and actresses set up their personal business in the typical food sector. The food is branded as a specific characteristic of city that increasingly marketed by Instagram, such as Makuta Bandung founded by Laudya Cintya Bella (370.000 followers, 3617 posts), Strudle Malang founded by Teuku Wisnu (133.000 followers, 4813 posts), Wife Cake owned by Chelsea Olivia (72.800 followers, 744 posts) and Wingkorolls in Semarang that is owned by Dewi Sandra. (37.200 followers, 1246 posts). By virtue of data, it shows differences of total follower and post in Wife Cake and Wingkorolls Instagram account in Semarang. It is interesting to examine "How does Wingkorolls escalate their follower through positioning form and brand on Instagram?". This research intends to describe Wingkorolls' e-marketing strategy on Instagram through IMC theory and emarketing tools. This research applies a qualitative descriptive method with semiotic analysis and in-depth interview to identify its positioning and brand. The output of this examination is that Wingkorolls has a positioning: typical food of Semarang, daily snack and as a present brought back from a trip for a family. Wingkorolls brand is known as premium, delicious, modern, unique and personal brand of Dewi Sandra also as an endorser of popular celebrity. Strategy pull marketing is used to create the promotion through interactive dialogue, network, and viral marketing or electronic worm to escalate awareness and interest.
\end{abstract}

Keywords: Instagram Marketing; Wingkorolls; IMC

\section{Introduction}

In media mass era nowadays bring change the marketing strategy in online business that utilized facebook, twitter, Instagram, etc as their marketplace. Instagram is social media that plenty of online business or personal business used. According to APJII 2016 [1], there are 15\% more Indonesian using Instagram than using youtube and twitter. $62 \%$ use media social for online shop and $34.2 \%$ utilize for personal business. Now many celebrities establish their personal business in city typical food sector marketed by Instagram, such as Bandung Makuta 
that Laudya Cintya Bella has founded, Strudle Malang by Teuku Wisnu, Wife Cake that Chelsea Olivia has and Wingkorolls by Dewi Sandra.

By the data, there are differences between total follower and post on Instagram between Wife Cake and Wingkorolls account in Semarang. The unique to observe is "How does Wingkorolls escalate their follower by positioning form and brand on Instagram?". The research aims to describe Wingkorolls e-marketing strategy on Instagram through IMC theory and e-marketing tools.

Table 1. Number of Followers and posts from Products

\begin{tabular}{lcc}
\hline \multicolumn{1}{c}{ Product } & Followers & Posts \\
& & \\
\hline Bandung Makuta & 370.000 & 3617 \\
Strudle Malang & 133.000 & 4813 \\
Wife Cake & 72.800 & 744 \\
Wingkorolls & 37.200 & 1246 \\
\hline & Source: [2], [3], [4], [5]
\end{tabular}

\section{Literature review}

\subsection{Integrated Marketing Communication (IMC)}

In a digital era, there are so many business marketers using Instagram as social media and also use approximation method Integrated Marketing Communication (IMC). It has a function to build positioning and positive brand to the consumer. With IMC, marketer attempt to synergy through a media with the result that consumer can catch a positive impression with the positioning and brand product. The strategy used by IMC to get the aim is using the AIDA concept (awareness, interest, desire, action). First, the consumer is made to be aware of the new product then will develop to have interest by the product's uniqueness through positioning and brand, after that will emerge desire to buy and the last, the consumer will be led to purchase [6], [7].

\subsection{E-Marketing Tools}

In e-marketing tools, there is viral marketing. If business media use Instagram, it is known as Instagram marketing. Instagram marketing contributes to making successful IMC because while building the awareness, interest, desire, and action to purchase are really influenced by caption while a posting on Instagram [6].

\section{Method}

This research uses qualitative descriptive method and data collecting method by analyzing every picture and video posted in Wingkorolls Instagram account with semiotic analysis technique Sander Pierce semiotic analysis technique to identify positioning and brand [8]. 


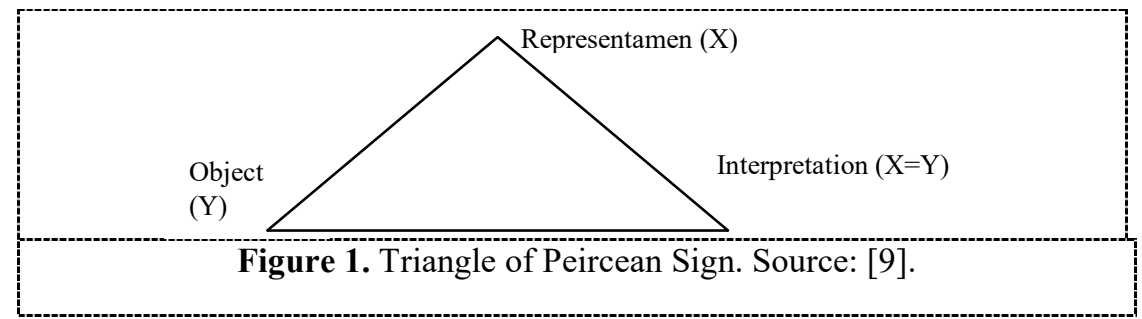

Semiotic is a technique to examine signs or the study of signs. This is related to the meaning of the word semiotic itself derived from the Greek "Semenion" which means sign. In practice, according to [10], this semiotic technique can be done through three main lines:

- Syntactic is a semiotic study that reveals the formal relationship between signs and the other signs.

- Semiotics is to examine the relationship of signs to objects they refer to.

- Pragmatic, pragmatics is to examine the relationship between signs and users and specifically deal with aspects of communication such as underlying situational functions.

According to Peirce, semiotics can be approached by three links; signs, objects (concepts, objects, and ideas), and interpretants or meanings obtained. These three according to Peirce always appear insignificance and as a triadic rather than binary structure as explained in the sign of Saussure semiotics [9], [11].

\section{Result and discussion}

\subsection{Positioning strategy and Wingkolls Brand}

Analyzing photos posted in Wingkorolls Instagram, we categorize them into a group of icon and symbol. It can be interpreted that Wingkorolls aim to build positioning. The positioning aimed is Wingkorolls as a typical food in Semarang, daily snack and present brought from a trip for a family. The brand that lifts Wingkorolls is premium, delicious, modern, unique and owned by Dewi Sandra as owner and also as an endorser of popular celebrity.

\subsection{Marketing strategy of Wingkorolls on Instagram}

From the research, it shows that Wingkorolls market the product using Instagram as social media and use pull strategy to develop awareness, interest, desire, and action to purchase of consumers.

To develop consumer awareness, wongkorolls post variant product, start from the wingko product, layered cake (lapis legit) with its quishy product. Because the product is new for people who lived in Semarang, the picture posted in Instagram has a design with other UMKM product which is more familiar for Semarang consumer in a frame. Thus, a consumer in Semarang will often know Wingkorolls product by seeing those umkm products. Another method is by posting every buyer in photobooth or their booth so that automatically the consumer's followers can see the Wingkorolls product. This is how marketing viral or Instagram marketing works. It relies on consumer's network to make the Wingkorolls product viral. 


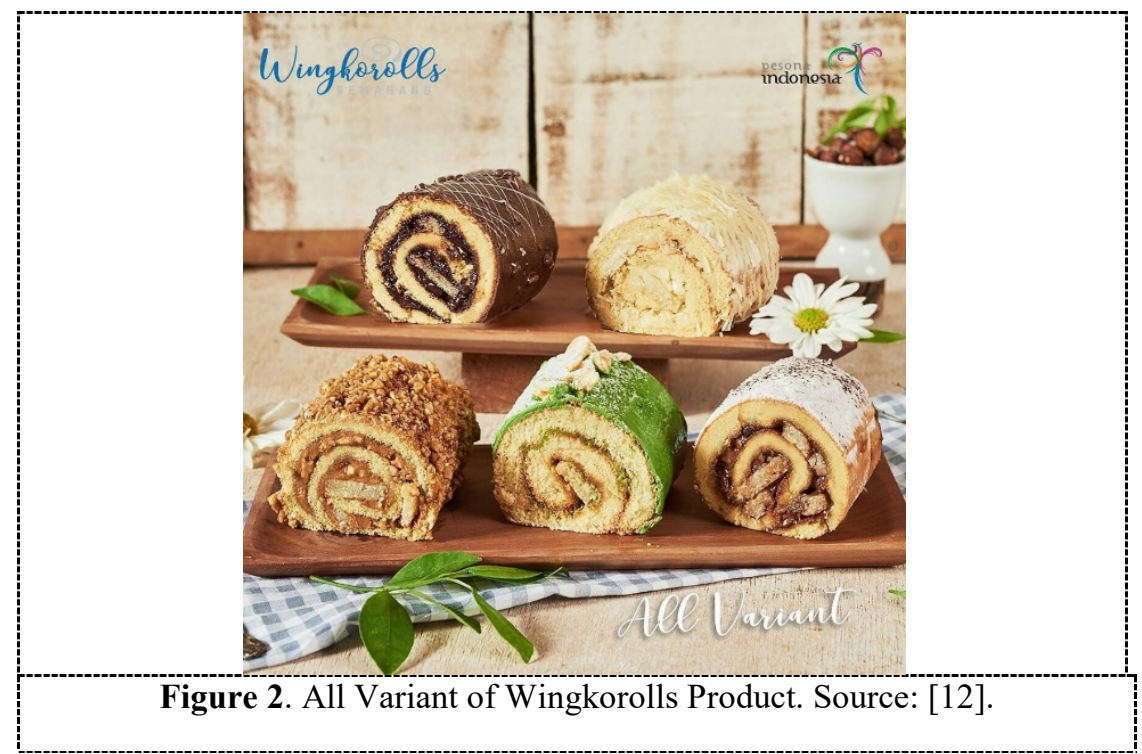

Wingkorolls strategy to make people more interest is by posting a photo of each product variant with modern, interesting and delicious-looking design. There are also photos of Wingkorolls variant product with a local product of Semarang food from UMKM around Semarang. Wingkorolls also post the tourism place photos and make a quiz for a consumer who becomes Wingkorolls followers on Instagram. It also always endorses Dewi Sandra herself and some celebrities such as Risky Alatas, Shireen Sungkar, Dini Aminarti, etc. By uploading the photos, the consumer will be interested in viewing Wingkorolls Instagram and becoming followers.

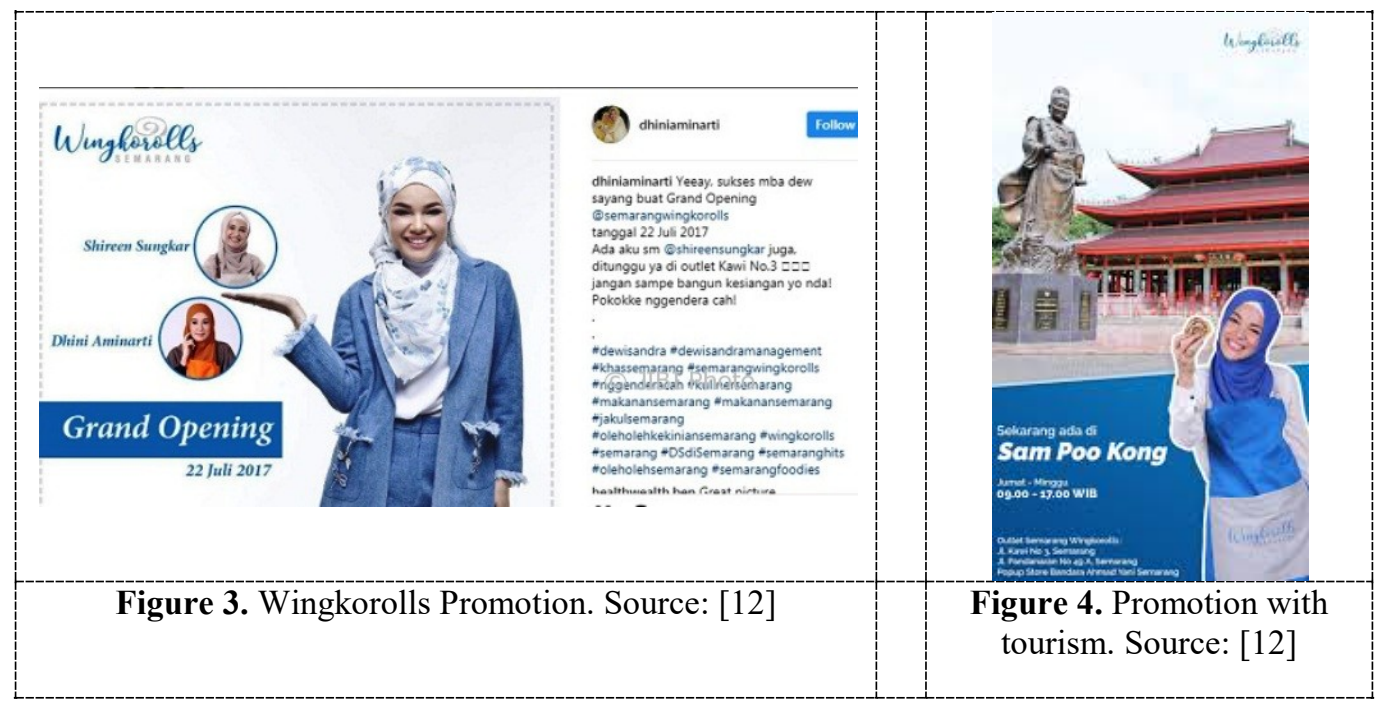


To increase consumer's desire to purchase, Wingkorolls upload photos of consumer who purchase, celebrity or public figure who buy and make some quizzes. The quizzes are Buyer's Photo in Wingkorolls Booth Quiz, Hashtag Quiz, 17th August Competition Quiz, Guess Word Quiz in Instagram video uploaded directly by Dewi Sandra, etc. The last method to lead the consumer to purchase is by posting a photo while open new stand in some tourism place and another place where people can take photos with Dewi Sandra or get present such as free Wingkorolls, etc.

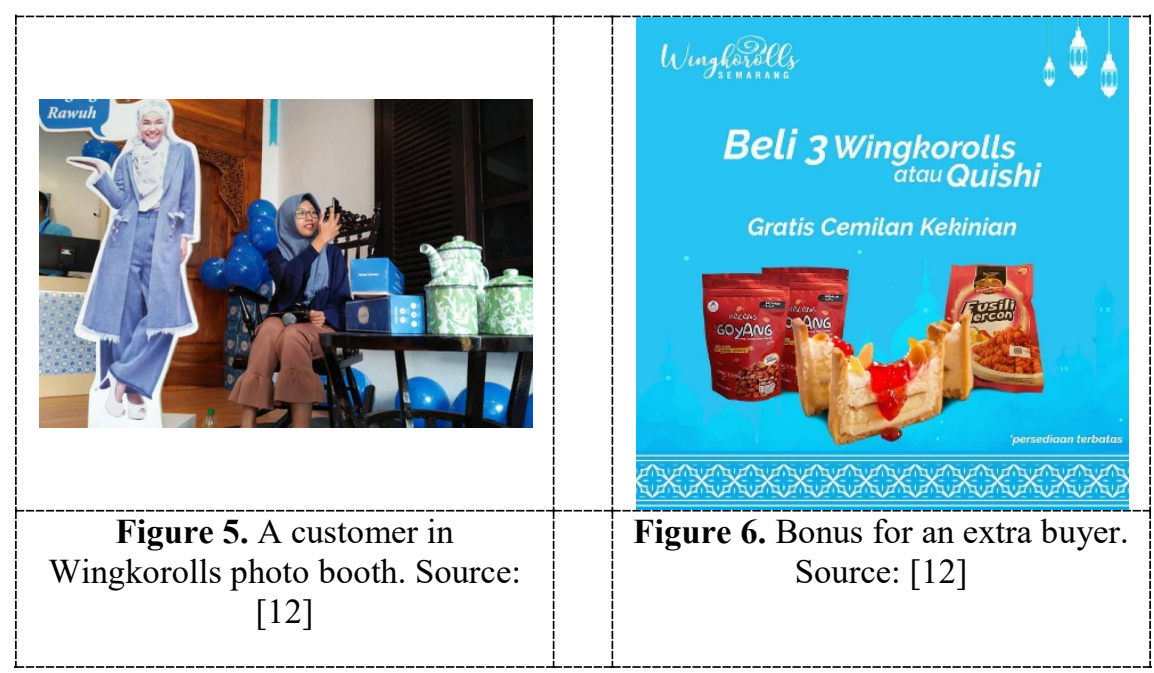

\section{References}

[1] A.P.J.I.I., "Saatnya Jadi Pokok Perhatian Pemerintah dan Industri," Buletin APJII, 2016.

[2] Wingkorolls, "Data Follower dan Postingan Wingkorolls," Instagram Wingkorolls. [Online]. Available: https://www.instagram.com/semarangwingkorolls/?hl=id.

[3] Instagram Semarang Wife Cake, "Data Follower dan Postingan Instagram Semarang Wife Cake," Instagram Semarang Wife Cake. [Online]. Available: https://www.instagram.com/semarangwifecake/?hl=id.

[4] Bandung Makuta, "Data Follower dan Postingan Bandung Makuta," Instagram Bandung Makuta. [Online]. Available: https://www.instagram.com/bandungmakuta/?hl=id.

[5] Strudel Malang, "Data Follower dan Postingan Instagram Strudel Malang," Instagram Strudel Malang. [Online]. Available: https://www.instagram.com/strudelmalang/?hl=id.

[6] K. P. Kotler and L. K. Kevin, Manajemen Pemasaran, vol. 13. Jakarta: Erlangga, 2009.

[7] M. Q. Denis, Teori Komunikasi Massa. Jakarta: Salemba Humanika, 2011.

[8] D. Mulyana, Metodologi Penelitian Kualitatif. Bandung: PT Remaja Rosdakarya, 2003.

[9] R. Nasrullah, Teori dan Riset Siber Media (Cybermedia), vol. 1. Jakarta: Kencana 
Prenadamedia Group, 2004

[10] K. Budiman, Semiotika Visual: Konsep, Isu, dan Problem Ikonositas. Yogyakarta: Jalasutra, 2011.

[11] M. Danesi, Message, Signs and Meanings: A Basic Texbook in Semiotics and Communication Theory. Toronto: Canadian Scholar's Press Inc, 2004.

[12] Wingkorolls, "Instagram Wingkorolls Semarang.". 